\title{
Estabelecimento de protocolo para micropropagação de Lippia gracilis Schauer
}

MARINHO, M.J.M.*; ALBUQUERQUE, C.C.; MORAIS, M.B.; SOUZA, M.C.G.; SILVA, K.M.B.

Universidade do Estado do Rio Grande do Norte, Departamento de Ciências Biológicas, BR 110, KM 46, Costa e Silva, CEP:59.600-970, Mossoró-Brasil *jocileidemm@gmail.com

\begin{abstract}
RESUMO: A espécie Lippia gracilis SCHAUER (Verbenaceae) é nativa do Nordeste brasileiro e se destaca pela capacidade de acumular nos tricomas glandulares óleos essenciais com atividade antimicrobiana. Tendo em vista que não constam trabalhos na literatura sobre o estabelecimento in vitro dessa espécie, este trabalho teve como objetivo estabelecer protocolo para micropropagação de L. gracilis. Para tanto, ramos contendo folhas foram coletados de plantas matrizes no habitat natural para a confecção de estacas. Em laboratório, os explantes provenientes do processo de estaquia foram assepticamente tratados e inoculados em meio MS, acrescido de fitorreguladores, com o intuito de se estabelecer a melhor dose para o desenvolvimento dos explantes. Em decorrência de altos níveis de contaminação, avaliou-se o efeito da cefalexina. No entanto, apesar do antibiótico ter apresentado diminuição na contaminação bacteriana, a porcentagem de oxidação foi elevada. Portanto, testou-se o carvão ativado, ácido ascórbico, ácido cítrico e metade dos sais de MS quanto a eficiência no controle da oxidação. Concluiu-se que, o antibiótico na concentração utilizada provocou a oxidação dos explantes e os fitorreguladores, bem como os métodos antioxidantes testados, não apresentaram resultados consistentes para o melhor desenvolvimento dos explantes e controle da oxidação, respectivamente.
\end{abstract}

Palavras-chave: Lippia gracilis, óleos essenciais, micropropagação

\begin{abstract}
Establishment of protocol for Lippia gracilis Schauer micropropagation. The species Lippia gracilis Schauer (Verbenaceae) is native to Northeastern Brazil and has been important for its ability to accumulate essential oils with antimicrobial activity in the glandular trichomes. Since there are no reports in the literature on the micropropagation of this species, the present work aimed to establish a protocol for L. gracilis micropropagation. Thus, branches containing leaves were collected from plant matrices in their natural habitat to prepare cuttings. In the laboratory, explants from cutting were aseptically treated and inoculated onto MS medium plus plant growth regulators in order to establish the best dose for the development of explants. Due to high levels of contamination, the effect of cephalexin was evaluated. Although the antibiotic decreased the bacterial contamination, the percentage of oxidation was high. Then, activated charcoal, ascorbic acid, citric acid and half the salts of MS were tested for their effectiveness to control oxidation. In conclusion, the used antibiotic concentration resulted in oxidation of explants. Furthermore, plant growth regulators and antioxidant methods did not show consistent results for a better development of explants and control of oxidation, respectively.
\end{abstract}

Key words: Lippia gracilis, essential oils, micropropagation

\section{INTRODUÇÃO}

As plantas nordestinas sempre tiveram grande importância para a população regional, pois de muitas espécies são retirados vários produtos que servem aos mais diversos fins. No entanto, poucas plantas são utilizadas em larga escala, em atividades que permitam grandes ganhos econômicos (Pereira et al., 2003), porque a extração e purificação de compostos, em muitos casos, tornam-se inviáveis economicamente, devido à pequena quantidade de princípio ativo resultante, demandando, em consequência disso, grande quantidade de material vegetal.

As reservas vegetais nativas, apesar de serem a única opção para certas drogas, não são inesgotáveis e o extrativismo puro e simples tem

Recebido para publicação em 03/07/2009

Aceito para publicação em 22/03/2010

Rev. Bras. PI. Med., Botucatu, v.13, n.2, p.246-252, 2011. 
consequências nefastas no que diz respeito à conservação das espécies de interesse (Pletsch, 1998). Nesse caso, a biotecnologia representa alternativa de produção em larga escala de plantas íntegras (Grattapaglia \& Machado, 1998), aumentando a oferta de certos compostos secundários, como por exemplo, os óleos essenciais.

Os óleos essenciais são originados do metabolismo secundário das plantas e possuem composição química complexa, destacando-se a presença de terpenos e fenilpropanóides (Gonçalves et al., 2003; Silva et al., 2003). Esses óleos estão relacionados com diversas funções necessárias à sobrevivência vegetal, exercendo papel fundamental na defesa contra microrganismos (Siqui et al., 2000), e são amplamente utilizados nas indústrias farmacêuticas (Harbone, 1992). Ainda, tem sido estabelecido cientificamente que cerca de $60 \%$ dos óleos essenciais possuem propriedades antifúngicas e $35 \%$ exibem propriedades antibacterianas (Bhavanani \& Ballow, 1992).

O gênero Lippia (Verbenaceae), nativo do Nordeste brasileiro, caracteriza-se pelo acúmulo de óleos essenciais em tricomas glandulares. Algumas das espécies, como por exemplo, Lippia gracilis Schauer, contém como principais compostos químicos timol e carvacrol, os quais são responsáveis pela atividade antimicrobiana já comprovada cientificamente (Matos et al., 1999; Pascual et al. 2001; Albuquerque et al, 2006; Oliveira et al., 2008). Essa espécie é utilizada também como antisséptica local, no tratamento da seborréia, na cura de impingem e dermatoses (Matos, 2002). Devido à capacidade de adaptação dessas plantas às condições climáticas da região Nordeste, a produção em larga escala desses óleos, poderá ser alternativa de renda para população da zona rural do semi-árido. O óleo essencial de Lippia sidoides, por exemplo, já vem sendo explorado do ponto de vista econômico pela empresa de Produtos Naturais Ltda (PRONAT) associada ao Parque de Desenvolvimento Tecnológico do Ceará (PADETEC) (Costa, 2006). A descoberta da potencialidade de outras espécies do mesmo gênero torna possível uma maior diversidade de compostos químicos com atividades farmacológicas semelhantes ou superiores às já conhecidas.

Embora as plantas do gênero Lippia sejam fontes de importantes compostos biologicamente ativos, as informações científico-agronômicas sobre estas plantas crescem em ritmo lento. Portanto, estudos a cerca de métodos adequados de propagação, bem como técnicas de cultivo são importantes na busca de soluções que resultem em maior produção de biomassa, além de garantir a perpetuação da espécie (Diniz et al., 2003).

Alguns trabalhos relacionados à propagação da Lippia já foram realizados e os resultados apontam para baixos percentuais de enraizamento e de sobrevivência de mudas produzidas a partir de estacas (Capote et al., 1999; Juliani Júnior et al., 1999).
A micropropagação, dentre outras técnicas da cultura de tecidos de plantas, tem proporcionado a obtenção de grande número de plantas com elevado nível qualitativo (Grattapaglia \& Machado, 1998).

Muitas plantas medicinais já são facilmente multiplicadas in vitro, tais como, Aloe vera (L.) Burm. F., com propriedades laxativas e cicatrizantes; Camptotheca acuminata Decne., com atividade anticancerígena; Egletes viscosa (L.) Less., antiespasmódica e antidiarréica; Artemisia annua L., utilizada para tratamento contra malária (Pletsch, 1998; Diniz et al., 2003; Liu et al., 2004). Por meio da micropropagação, é possível aumentar a oferta de compostos biologicamente ativos e diminuir o preço dos princípios ativos fitoquímicos (Bajaj et al., 1988; Miachir, 1992; Pletsch, 1998). Com relação ao cultivo in vitro do gênero Lippia, alguns trabalhos já foram realizados com resultados satisfatórios (Capote et al., 1999; Gupta et al., 2001; Peixoto et al, 2006; Costa et al., 2007).

Sendo assim, como a técnica da micropropagação já vem sendo empregada para a produção em larga escala de espécies medicinais, forrageiras, frutíferas, florestais e ornamentais, também poderá ser aplicada às espécies vegetais produtoras de metabólitos secundários úteis aos seres vivos de modo que as espécies possam ser explorada economicamente. Portanto, o presente trabalho tem como objetivo estabelecer um protocolo para a micropropagação da espécie Lippia gracilis Schauer.

\section{MATERIAL E MÉTODO}

O trabalho foi conduzido em casa de vegetação e no Laboratório de Cultura de Tecidos Vegetais, da Universidade do Estado do Rio Grande do Norte, Mossoró-RN, entre os meses de agosto de 2007 e julho de 2008.

O material vegetal utilizado foi coletado na cidade de Felipe Guerra - RN. Ramos contendo folhas foram retirados da planta matriz com auxílio de tesoura de poda e armazenados em sacos de nylon para o transporte. Em casa de vegetação, procedeuse a retirada das folhas e preparo das estacas, as quais foram colocadas em bandejas contendo como substrato húmus e areia (na proporção de 1:1). As bandejas permaneceram em casa de vegetação, onde, durante os primeiros 20 dias as estacas receberam tratamento com solução nutritiva ( $1 / 4$ dos sais de MS acrescido de $2 \mathrm{~mL} \mathrm{~L}^{-1}$ de ANA- Ácido naftalenoacético) a cada dois dias. Após o primeiro mês de plantio das estacas o ANA foi suprimido da solução e as mudas que sobreviveram foram transplantadas para sacos de polietileno com capacidade para $1 \mathrm{~kg}$, contendo areia fina, areia grossa e húmus como substrato (na proporção de 1:1:1), onde permaneceram por mais 58 dias. Após esse período, as mudas resultantes foram transferidas para o solo em uma área do

Rev. Bras. PI. Med., Botucatu, v.13, n.2, p.246-252, 2011. 
Campus da UERN, sendo desde então mantidas e utilizadas como fonte de explantes para a montagem dos experimentos em laboratório.

Com o intuito de se estabelecer um protocolo para micropropagação in vitro da espécie $L$. gracilis que proporcione a multiplicação em larga escala num espaço de tempo reduzido, foram conduzidos diferentes experimentos.

\section{a) Avaliação de 6-benzilaminopurina e do ácido naftalenoacético (ANA) na micropropagação de L. gracilis}

Em laboratório, brotos jovens obtidos a partir das mudas provenientes do processo de estaquia foram lavados em água corrente por 30 minutos. Durante esse período realizou-se também à retirada das folhas e o corte dos brotos em microestacas com aproximadamente $2 \mathrm{~cm}$ de comprimento. Em seguida, as microestacas permaneceram sob agitação em água com detergente comercial ( 10 gotas $\left.\mathrm{L}^{-1}\right)$ por 10 minutos, e submetidas a três lavagens consecutivas com água destilada esterilizada (ADE).

As microestacas foram levadas para câmara de fluxo laminar contínuo, onde foram tratadas assepticamente com álcool a $70 \%$ por 1 minuto, hipoclorito de cálcio $(\mathrm{CaOCl})$ a $3 \%$ por 10 minutos e três lavagens consecutivas com ADE. Posteriormente, as microestacas foram seccionadas em segmentos nodais, conservando-se uma gema por segmento e inoculadas em tubos de ensaio contendo $10 \mathrm{~mL}$ de meio de cultura MS (Murashige \& Skoog, 1962), suplementado com $30 \mathrm{~g} \mathrm{~L}^{-1}$ de sacarose, $6,5 \mathrm{~g} \mathrm{~L}^{-1}$ de ágar, e diferentes combinações de 6benzilaminopurina (BAP) e ácido naftalenoacético (ANA). $\mathrm{O} \mathrm{pH}$ do meio de cultura foi ajustado para 5,8 $\pm 0,1$ antes da esterilização em autoclave $\left(121^{\circ} \mathrm{C}\right.$ durante 20 minutos). $O$ delineamento experimental foi o inteiramente casualizado com 6 repetições em esquema fatorial $3^{2}$, onde, foram testados 2 fitorreguladores em três concentrações (BAP: 0,0; 1,0 e $2,0 \mathrm{mg} \mathrm{L}^{-1}$ e ANA: 0,$0 ; 0,1$ e $0,5 \mathrm{mg} \mathrm{L}^{-1}$ ) combinadas ou não, perfazendo um total de nove tratamentos. A unidade experimental constou de quatro tubos de ensaio, cada tubo contendo um explante. As variáveis propostas para avaliação nesse experimento foram comprimento dos brotos e taxa de multiplicação em função do número de segmentos nodais obtidos por planta aos 30, 60, 90 e 120 dias.

b) Influência de concentrações de cefalexina no estabelecimento in vitro de $L$. gracilis

Em virtude da alta taxa de contaminação bacteriana apresentada por esta espécie no experimento com os fitorreguladores, avaliou-se a eficiência do antibiótico cefalexina. Para tanto, seguiuse a mesma metodologia de assepsia de brotos coletados de plantas matrizes, porém, o desinfestante utilizado foi o hipoclorito de sódio ( $\mathrm{NaOCl}$ ) a 2,5\% de cloro ativo. As microestacas foram subdivididas em segmentos nodais e inoculadas em frascos contendo $25 \mathrm{~mL}$ de meio de cultura MS. O delineamento experimental foi o inteiramente casualizado, com duas doses de cefalexina ( 0 e $200 \mathrm{mg} \mathrm{L}^{-1}$ ) e cinco repetições, sendo cada repetição constituída por nove frascos contendo um explante cada. Após 30 dias, foram avaliados o número de brotos, a porcentagem de contaminação e a porcentagem de oxidação.

Em câmara de fluxo laminar contínuo, o antibiótico foi esterilizado a frio por filtração (Millipore, $0,45 \mu \mathrm{m}$ ) e adicionado ao meio de cultura quando este estava em processo de resfriamento $\left(40\right.$ a $\left.50^{\circ} \mathrm{C}\right)$, cinco dias antes da montagem do experimento.

c) Avaliação de métodos antioxidantes visando minimizar os problemas de oxidação em explantes de $L$. gracilis

Em decorrência dos problemas enfrentados com a oxidação dos explantes, foram testados diferentes métodos para minimizar o problema: dois antioxidantes (ácido ascórbico - $100 \mathrm{mg} \mathrm{L}^{-1} \mathrm{e}$ ácido cítrico - $\left.100 \mathrm{mg} \mathrm{L}^{-1}\right)$; Carvão ativado (3 $\mathrm{g} \mathrm{L}^{-1}$ ); metade da concentração dos sais de MS. A metodologia para obtenção dos segmentos nodais assepticamente tratados foi a mesma utilizada em experimentos anteriores, no entanto, baseado em ensaios preliminares adotou-se o hipoclorito de sódio ( $\mathrm{NaOCl}$ ) a $1 \%$ de cloro ativo como desinfestante. $O$ experimento foi em delineamento inteiramente casualizado, composto por cinco tratamentos, com cinco repetições cada. A unidade experimental constou de quatro tubos de ensaio, contendo um explante cada. Após 15 dias avaliou-se a porcentagem de oxidação e de sobrevivência.

Em todos os experimentos realizados em laboratório, os frascos ou tubos de ensaio contendo os explantes foram mantidos em sala de crescimento com temperatura média de $25+2^{\circ} \mathrm{C}$ e fotoperíodo de 16 durante os períodos especificados em cada etapa. As médias obtidas para cada variável foram avaliadas pelo Teste de Tukey ao nível $5 \%$ de probabilidade.

\section{RESULTADO E DISCUSSÃO}

\section{a) Avaliação de 6-benzilaminopurina e do ácido naftalenoacético na micropropagação de L. gracilis}

No presente trabalho, durante o cultivo in vitro dos explantes de $L$. gracilis com ANA e BAP, observouse intensa oxidação e formação de calos em praticamente todos os tratamentos (Tabela 1). Certamente, os fitorreguladores juntamente com os fitohormônios proporcionaram um balanço hormonal para resultar em proliferação de calos. No entanto, outros autores obtiveram sucesso na micropropagação 
de espécies de Lippia com a adição das mesmas classes de fitorreguladores, embora em alguns trabalhos a concentração desses reguladores tenham sido diferentes. Em Lippia sidoides Cham, testou-se diferentes reguladores de crescimento e concluiu-se que a concentração de $0,1 \mathrm{mg} \mathrm{L}^{-1}$ de BAP promoveu maior acúmulo de matéria fresca nas folhas dessa espécie micropropagada em meio de cultura MS (Costa, 2006). Com a Lippia alba, cultivar Kavach, a regeneração de plantas foi obtida utilizando-se gemas apicais e meio MS contendo 2,0 $\mu \mathrm{M} \mathrm{L}^{-1}$ de BAP (Gupta et al., 2001). Já para Lippia micromera, variedade Helleri, observou-se que os melhores resultados de multiplicação ocorreram quando se utilizou o meio MS acrescido de $0,1 \mathrm{mg} \mathrm{L}^{-1}$ de ácido naftalenoacético (ANA) + 2,0 $\mathrm{mg} \mathrm{L}^{-1}$ de BAP (Capote et al., 1999).

Além dos problemas relacionados à oxidação e formação de calos, observou-se frequente crescimento bacteriano no meio de cultura, ocasionando uma grande perda dos explantes, impossibilitando a avaliação das variáveis propostas inicialmente (Tabela 1). Possivelmente tais taxas elevadas de contaminação estejam diretamente relacionadas à época do ano, tendo em vista que os ensaios conduzidos anteriormente em épocas com menores índices pluviométricos não apresentaram este tipo de problema.

\section{b) Influência de concentrações de cefalexina no estabelecimento in vitro de $L$. gracilis}

No que diz respeito ao uso do antibiótico cefalexina, observou-se uma redução na contaminação bacteriana na dose de $200 \mathrm{mg} \mathrm{L}^{-1}$, porém não foi estatisticamente significante. Entretanto, o antibiótico influenciou negativamente o desenvolvimento dos explantes, causando elevada porcentagem de oxidação e redução no número de brotações dos mesmos (Tabela 2).

TABELA 1. Porcentagem de contaminação bacteriana, oxidação e formação de calos em explantes de L. gracilis em função das concentrações de 6-Benzilaminopurina (BAP) e Ácido naftalenoacético (ANA). Mossoró, UERN, 2009.

\begin{tabular}{crrr}
\hline $\begin{array}{c}\text { BAP/ANA } \\
\left(\text { mg L L }^{-1}\right)\end{array}$ & $\begin{array}{r}\text { Contaminação } \\
(\%)\end{array}$ & $\begin{array}{c}\text { Oxidação } \\
(\%)\end{array}$ & $\begin{array}{c}\text { Formação de } \\
\text { Calos }(\%)\end{array}$ \\
\hline $0,0 / 0,0$ & $38,56 \mathrm{a}$ & $10,40 \mathrm{a}$ & $1,28 \mathrm{a}$ \\
$0,0 / 0,1$ & $37,38 \mathrm{a}$ & $7,36 \mathrm{a}$ & $7,36 \mathrm{a}$ \\
$0,0 / 0,5$ & $36,38 \mathrm{a}$ & $10,40 \mathrm{a}$ & $8,00 \mathrm{a}$ \\
$1,0 / 0,0$ & $37,47 \mathrm{a}$ & $7,36 \mathrm{a}$ & $7,36 \mathrm{a}$ \\
$1,0 / 0,1$ & $39,56 \mathrm{a}$ & $4,32 \mathrm{a}$ & $4,32 \mathrm{a}$ \\
$1,0 / 0,5$ & $38,56 \mathrm{a}$ & $7,36 \mathrm{a}$ & $4,32 \mathrm{a}$ \\
$2,0 / 0,0$ & $35,00 \mathrm{a}$ & $10,40 \mathrm{a}$ & $10,40 \mathrm{a}$ \\
$2,0 / 0,1$ & $32,47 \mathrm{a}$ & $14,88 \mathrm{a}$ & $10,40 \mathrm{a}$ \\
$2,0 / 0,5$ & $36,29 \mathrm{a}$ & $10,40 \mathrm{a}$ & $7,36 \mathrm{a}$ \\
\hline Média & $36,85 \%$ & $9,21 \%$ & $6,76 \%$ \\
C.V. & 26,50 & 80,44 & 70,52 \\
\hline
\end{tabular}

${ }^{1}$ Dados transformados para arco seno da raiz de (x/100); ${ }^{2}$ Médias seguidas por letras iguais na mesma coluna não diferem entre si pelo teste de Tukey $(p<0,05)$.

TABELA 2. Porcentagem de contaminação, oxidação e o número médio de brotos/explantes de Lippia gracilis Schauer sob a influência de duas concentrações de cefalexina. Mossoró, UERN, 2009.

\begin{tabular}{lccc}
\hline \multicolumn{1}{c}{ Tratamento } & $\begin{array}{c}\text { Contaminação } \\
(\%)\end{array}$ & $\begin{array}{c}\text { Oxid ação }^{1} \\
(\%)\end{array}$ & $\begin{array}{c}\text { No })^{-} \\
\text {Brotos/Explante }^{2}\end{array}$ \\
\hline $0,0 \mathrm{mg} \mathrm{L}^{-1}$ de Cefalexina & $10,30 \mathrm{a}$ & $33,30 \mathrm{a}^{*}$ & $4,38 \mathrm{a}^{* \star}$ \\
$200,0 \mathrm{mg} \mathrm{L}^{-1}$ de Cefalexina & $8,58 \mathrm{a}$ & $51,42 \mathrm{~b}$ & $2,63 \mathrm{~b}$ \\
\hline Média Geral & $9,44 \%$ & $42,36 \%$ & 3,50 \\
C.V. & 88,13 & 25,54 & 11,22 \\
\hline
\end{tabular}

${ }^{*}$ Significativo pelo Teste de Tukey $(p<0,05)^{*}$ e $(p<0,01)^{* *} ;{ }^{1}$ Dados transformados para arco seno da raiz de $(x / 100) ;{ }^{2} O s$ valores são as médias transformadas em sqrt $(x+0,05)$; Médias com letras iguais na mesma coluna não diferem entre si pelo Teste de Tukey $(p<0,05)$. 
Certamente a dosagem do antibiótico utilizada foi elevada, causando fitotoxidez nos explantes de L. gracilis. No entanto, Costa (2006) obteve maior sobrevivência de explantes e menor crescimento bacteriano com a utilização de $200 \mathrm{mg}$ $\mathrm{L}^{-1}$ de cefotaxina sódica na micropropagação de alecrim-pimenta (Lippia sidoides Chan.). Esse antibiótico pertencente à classe das cefalosporinas, mesmo sub-grupo que a cefalexina. Mesmo que se utilizem antibióticos de amplo espectro, o controle bacteriano na cultura de tecidos é problemático. $\mathrm{Na}$ maioria dos trabalhos in vitro, a inibição da contaminação não é total, pois, os tecidos vegetais podem interferir no controle por meio da desintoxicação destas substâncias ou servindo como habitat para os contaminantes que se translocam pelos seus tecidos. É comum que as concentrações de antibióticos devam ser elevadas quando estes são adicionados ao meio nutritivo juntamente com o explante, no entanto a fitotoxidez dessas substâncias é fator limitante dessas concentrações (Pereira \& Fortes, 2003). Uma das alternativas para se evitar o efeito tóxico dos antibióticos sobre os explantes é reduzir ao máximo o tempo do tratamento (contato) dos explantes com o agente antimicrobiano. No entanto, esta técnica muitas vezes causa efeitos apenas bacteriostáticos, constituindo ação paliativa frente ao principal objetivo que seria a eliminação por completo do organismo contaminante (Pereira et al., 2003). Portanto, diante dos resultados, faz-se necessário a realização de novos ensaios com outras classes de antibióticos em diferentes concentrações.

\section{c) Avaliação de métodos antioxidantes visando minimizar os problemas de oxidação em explantes de $L$. gracilis}

No que tange as taxas de oxidação, uma alternativa para contorná-la, independentemente da causa, seria a adição de substâncias antioxidantes ao meio de cultivo, ou a redução à metade das concentrações salinas do meio de cultura. Segundo Grattapaglia \& Machado (1998), a adição de substâncias antioxidantes ao meio de cultivo ou o pré-tratamento, em solução de antioxidantes, diminui a oxidação.

No presente trabalho, quando foram avaliados os métodos antioxidantes verificou-se que, embora tenham sido aplicados os procedimentos mais indicados no controle da oxidação fenólica, não houve diferenças significativas entre a presença e ausência de antioxidantes para a porcentagem de oxidação, sendo esta observada em níveis bem elevados (Tabela 3). Provavelmente, outros fatores estejam relacionados aos altos níveis de oxidação encontrada nos diferentes tratamentos, como a época do ano, a idade do explante, ou os mecanismos de defesa da planta, expressos através da produção de polifenóis, os quais sofrem ação das polifenases provocando o escurecimento do explante e/ou do meio. Resultados semelhantes foram observados por Erig \& Schuch (2003) quando verificaram que concentrações de 50 a $200 \mathrm{mg} \mathrm{L}^{-1}$ de ácido ascórbico no meio de cultura não inibiu a oxidação dos explantes de macieira (Malus domestica Borkh.), e por Gupta (1986) que verificou que o ácido cítrico e o carvão ativado foram menos efetivos no controle da oxidação em explantes de diferentes cultivares de banana. Com isso, tornase necessária a realização de novos ensaios a fim de se testar outros antioxidantes e provavelmente outras concentrações dos antioxidantes testados neste trabalho.

Quanto ao número de brotos formados, verificou-se que também não houve diferença estatisticamente significante, no entanto pode-se observar melhores índices de brotações nos tratamentos com carvão ativado e com $1 / 2$ dos sais

TABELA 3. Porcentagem de oxidação e média do número de brotos/explante de Lippia gracilis Schauer submetidos a diferentes métodos antioxidantes. Mossoró, UERN, 2009.

\begin{tabular}{lcc}
\hline \multicolumn{1}{c}{ Tratamentos } & $\begin{array}{c}\text { Oxidação } \\
(\%)\end{array}$ & $\begin{array}{c}\text { Número de } \\
\text { Brotos/Explante }\end{array}$ \\
\hline Controle & $21,84 \mathrm{a}$ & $1,24 \mathrm{a}$ \\
$100 \mathrm{mg} \mathrm{L}^{-1}$ de ácido ascórbico & $22,37 \mathrm{a}$ & $1,10 \mathrm{a}$ \\
$100 \mathrm{mg} \mathrm{L}^{-1}$ de ácido cítrico & $21,50 \mathrm{a}$ & $1,33 \mathrm{a}$ \\
$3 \mathrm{~g} \mathrm{~L}^{-1}$ de carvão ativado & $21,84 \mathrm{a}$ & $3,03 \mathrm{a}$ \\
$1 / 2$ dos sais de MS & $21,84 \mathrm{a}$ & $2,40 \mathrm{a}$ \\
\hline Média Geral & $21,88 \%$ & 1,82 \\
C.V & 20,47 & 63,94 \\
\hline
\end{tabular}

1Dados transformados para arco seno da raiz de $(x / 100) ;{ }^{2}$ Os valores são as médias transformadas em sqrt $(x+0,05)$; "Médias com letras iguais na mesma coluna não diferem entre si pelo Teste de Tukey $(p<0,05)$.

Rev. Bras. PI. Med., Botucatu, v.13, n.2, p.246-252, 2011. 
de MS (Tabela 3). Esse resultado já era esperado em relação ao carvão ativado, um dos antioxidantes químicos notadamente utilizados em diversos protocolos (George, 1996), podendo ser confirmado pelos resultados de Melo et al. (2001), que observaram que para todas as variáveis avaliadas o carvão ativado na concentração de $1,5 \%$, foi um dos antioxidantes mais eficazes.

Com relação à redução dos sais de $\mathrm{MS}$, alguns autores relatam que a taxa de oxidação diminuiu (Utino et al., 2001), no entanto, nesse trabalho não se observou diferença significativa entre 0 tratamento com metade de MS e o tratamento controle, e sim que, quanto menor a taxa de oxidação, melhores foram os resultados quanto a formação de novos brotos.

É relevante ainda ressaltar que além dos fatores já mencionados que podem ocasionar a oxidação fenólica no processo de micropropagação, alguns gêneros de plantas são mais suscetíveis à oxidação que outros, apesar da oxidação fenólica ser altamente dependente do genótipo (Teixeira, 2001).

\section{CONCLUSÃO}

- Os fitorreguladores ANA e BAP, nas concentrações avaliadas apenas proporcionaram formação de calo;

A dose de $200 \mathrm{mg} \mathrm{L}^{-1}$ de cefalexina inibiu a contaminação, mas provocou a oxidação e reduziu a formação de novos brotos;

- Os diferentes métodos antioxidantes testados não inibiram a oxidação em explantes de $L$. gracilis.

\section{AGRADECIMENTO}

Ao Conselho Nacional de Desenvolvimento Científico e Tecnológico (CNPq) e à Universidade do Estado do Rio Grande do Norte (UERN) pelo apoio financeiro.

\section{REFERÊNCIA}

ALBUQUERQUE, C.C. et al. Antimicrobial action of the essential oil of Lippia gracilis Schauer. Brazilian Archives of Biology and Technology, v.49, n.4, p.527-35, 2006.

BAJAJ, Y.P.S.; FURMANOWA, M.; OLSZOWSK, O. Biotechnology of the micropropagation of medicinal and aromatic plants. In: BAJAJ, Y.P.S. Biotechnology in Agriculture and Foresty, v.4, p.60-103, 1988.

BHAVANANI, S.M.; BALLOW C.H. New agents for Grampositive bacteria. Current Opinion in Microbiology, v.13, p.528-34, 1992.

CAPOTE, A. et al. Micropropagación y regeneración de plantas in vitro de oreganillo Lippia micromera Schau. Revista Del Jardín Botânico Nacional, v.10, p.139-42, 1999.
COSTA, A.S. Sustentabilidade da produção de alecrimpimenta (Lippia sidoides Cham.): micropropagação visando a conservação in vitro. 2006. 70p. Dissertação (Mestrado em Agroecossistemas) - Universidade Federal de Sergipe, São Cristóvão.

COSTA, A.S. et al. Estabelecimento de alecrim-pimenta in vitro. Horticultura Brasileira, v.25, n.1, p.68-72, 2007. DINIZ, J.D.N. et al. Ácido giberélico $\left(\mathrm{GA}_{3}\right)$ e 6 benzilaminopurina (BAP) no crescimento in vitro de macela [Egletes viscosa (L.) Less.]. Ciência e Agrotecnologia, v.27, n.4, p.934-8, 2003.

ERIG, A.C.; SCHUCH, M.W. Tipo de explante e controle da contaminação e oxidação no estabelecimento in vitro de plantas de macieira (Malus domestica Borkh) cvs. Galaxy, Maxigala e Mastergala. Revista Brasileira de Agrociência, v.9, n.3, p.221-7, 2003.

GEORGE, E.F. Plant propagation by tissue culture. Edington: Exegeties, 1996. 1361p.

GONÇALVES, L.A. et al. Produção e composição do óleo essencial de alfavaquinha (Ocimim selloi Benth.) em resposta a dois níveis de radiação solar. Revista Brasileira de Plantas Medicinais, v.6, n.1, p.8-14, 2003. GRATTAPAGLIA, D.; MACHADO, M.A. Micropropagação. In: TORRES, A.C.; CALDAS, L.S. Técnicas e aplicações da cultura de tecidos de plantas. Brasília: ABCTP/ EMBRAPA CNPH, 1990. p.99-169.

GUPTA, P.P. Erradication of mosaic disease and rapid clonal multiplication of bananas and plantains through meristem tip culture. Plant Cell Tissue and Organ Culture, v.6, p.33-9, 1986.

GUPTA, S.K.; KHANUJA, S.P.S.; KUMAR, S. In vitro micropropagation of Lippia alba. Current Science, v.81, n.2, p.206-10, 2001

HARBONE, J.B. Introduction to ecological biochemistry. 4.ed. Londom: Academic Press, 1992. 318p.

JULIANI, J.R. et al. Microprpagation of Lippia junelliana (Mold.) Tronc. Plant Cell, Tissue and Organ Culture, v.59, p.175-9, 1999.

LIU, C.Z. et al. Artemisia judaica L.: micropropagation and antioxidant activity. Journal of Biotechnology, v.110, p.63-71, 2004.

MATOS, F.J.A. Farmácias vivas. 4 ed. Fortaleza: Edições UFC, 2002. 267p.

MATOS, F.J.A. et al. Medicinal plants northeast Brazil containing thymol and carvacrol - Lippia sidoides Cham. and $L$. gracillis H. B. K (Verbenaceae). Journal of Essential Oil Research, v.11, p.666-8, 1999.

MELO, B. et al. Diferentes antioxidantes no controle da oxidação, germinação e desenvolvimento das plântulas na cultura in vitro de embriões de guarirobeira [Syagrus oleracea (MART.) BECC]. Ciência e Agrotecnologia, v.25. p.1301-6, 2001.

MIACHIR, J.I. Proposição de um protocolo de cultura de tecidos para produção de compostos secundários para Curcuma zeadoaria Roscoe. 1992. 126p. Dissertação (Mestrado em Fisiologia e Bioquímica de Plantas) - Escola Superior de Agricultura Luiz de Queiroz, Piracicaba.

MURASHIGE, T.; SKOOG, F. A revised medium for rapid growth and bioassays with tobacco tissue cultures. Physiology Plantarum, v.15, p.473-97, 1962.

OLIVEIRA, O.R. Efeito de óleos essenciais de plantas do gênero Lippia sobre fungos contaminantes 
encontrados na micropropagação de plantas. Revista Ciência Agronômica, v.39, n.1, p.94-100, 2008.

PASCUAL, M.E. et al. Lippia: traditional uses, chemistry and pharmacology: a review. Journal of Ethnopharmacology, v.76, n.3, p.201-14, 2001.

PEIXOTO, P. et al. In vitro propagation of endangered Lippia filifolia Mart. and Schauer ex Schauer. In Vitro Cellular and Development Biology Plant, v.42, n.6, p.55861, 2006.

PEREIRA, J.E.S.; FORTES, G.R.L. Toxicidade de antibióticos no cultivo in vitro de batata em meios semisólido e líquido. Pesquisa Agropecuária Brasileira, v.38, n.11, p.1273-9, 2003.

PEREIRA, S.C. et al. Plantas úteis do Nordeste do Brasil. Recife: Centro Nordestino de Informações sobre Plantas - CNIP, Associação Plantas do Nordeste - APNE, 2003. 140p.

PLETSCH, M. Compostos naturais biologicamente ativos. Biotecnologia Ciência \& Desenvolvimento, v.4, p.12-5, 1998.

SILVA, A.F. et al. Composição química do óleo essencial de Hyptis suaveolens (L.) Poit. (Lamiaceae). Revista Brasileira de Plantas Medicinais, v.6, p.1-7, 2003.

SIQUI, A.C. et al. Óleos essenciais - potencial antiinflamatório. Biotecnologia, Ciência e Desenvolvimento, v.16, p.38-43, 2000.

TEIXEIRA, J.B. Limitações ao processo de cultivo in vitro de espécies lenhosas. In: ENCONTRO LATINOAMERICANO DE BIOTECNOLOGIA VEGETAL, 4., 2001, Goiânia, Simpósios... Goiânia: REDBIO, 2001. UTINO, S.; CARNEIRO, I.F.; CHAVES, L.J. Crescimento e oxidação de explantes de bananeira prata (Musa AAB) in vitro: IV. Concentrações de sais, ácidos ascórbicos e freqüência de subcultivos. Revista Brasileira de Fruticultura, v.23, n.2, p.409-12, 2001. 